
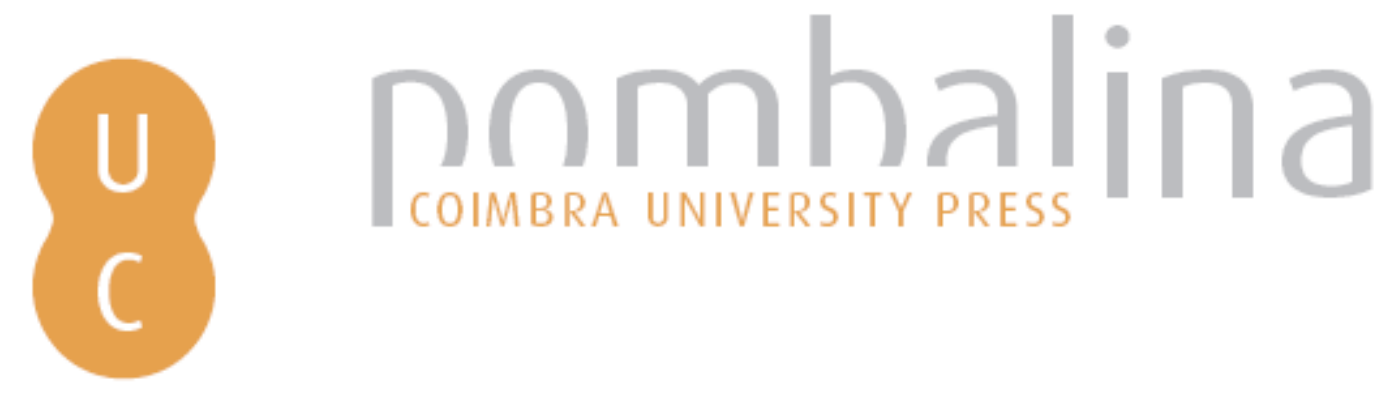

\title{
Polis and imperium: two ancient political ideas, and their echoes in some modern political reflections
}

\author{
Autor(es): $\quad$ Desideri, Paolo \\ Publicado por: Imprensa da Universidade de Coimbra \\ URL \\ persistente: URI:http://hdl.handle.net/10316.2/44718 \\ DOI: $\quad$ DOl:https://doi.org/10.14195/978-989-26-1564-6_3 \\ Accessed : $\quad$ 26-Apr-2023 05:14:50
}

A navegação consulta e descarregamento dos títulos inseridos nas Bibliotecas Digitais UC Digitalis, UC Pombalina e UC Impactum, pressupõem a aceitação plena e sem reservas dos Termos e Condições de Uso destas Bibliotecas Digitais, disponíveis em https://digitalis.uc.pt/pt-pt/termos.

Conforme exposto nos referidos Termos e Condições de Uso, o descarregamento de títulos de acesso restrito requer uma licença válida de autorização devendo o utilizador aceder ao(s) documento(s) a partir de um endereço de IP da instituição detentora da supramencionada licença.

Ao utilizador é apenas permitido o descarregamento para uso pessoal, pelo que o emprego do(s) título(s) descarregado(s) para outro fim, designadamente comercial, carece de autorização do respetivo autor ou editor da obra.

Na medida em que todas as obras da UC Digitalis se encontram protegidas pelo Código do Direito de Autor e Direitos Conexos e demais legislação aplicável, toda a cópia, parcial ou total, deste documento, nos casos em que é legalmente admitida, deverá conter ou fazer-se acompanhar por este aviso.

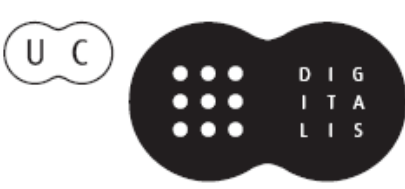




\section{História Antiga:}

Relações

Interdisciplinares.

Fontes, Artes, Filosofia,

Política, Religião e Receção

\section{Carmen Soares, José Luís Brandão \& Pedro C. Carvalho (coords.)}




\title{
Polis AND imperium: TWo ANCIENT POLITICAL IDEAS, AND THEIR ECHOES IN SOME MODERN POLITICAL REFLECTIONS
}

\author{
Paolo Desideri (paolo.desideri@unifi.it) \\ former Prof. of Roman History in the University of Firenze
}

Abstract - As is well known, polis and imperium are the two fundamental political models which were developed in classical times, by the Greeks and the Romans respectively. In principle, the two models are mutually exclusive, but from Cicero's idea of (a sort of) 'double - civic and imperial - citizenship' (De legibus) on, efforts have been made towards envisaging the possibility of some compatibility between them. On the other hand, after Alexander's conquest of the Persian realm, the Greek political thought had also apparently begun to accept the idea of a political structure capable of gathering together many different cities and peoples: a cosmopolis. This was probably the leading idea of the Politeia written by the Stoic philosopher Zeno; or, at least, this was the interpretation of that text proposed by Plutarch, who wrote at the beginning of the best period of the Roman Empire. And in the generation following Plutarch, in his Roman Oration the Smyrnean sophist Aelius Aristides went so far as to imagine the Roman Empire as a sort of federation of poleis under the supreme direction of the emperor. In this way, the ancient political thought tried to overcome the old dichotomy between the two fundamentally opposed political models of polis and imperium. During the Middle Ages, both in the Western and in the Eastern parts of the former Roman Empire the idea of empire remained the only accepted political idea, even though, with the twelfth and thirteenth centuries, new political structures at a civic level began to appear in Northern and Central Italy. Rediscovering the principles of self-government, in a way these political structures repeated the ancient polis-model. But for this model to gain theoretical legitimization, it needed to wait for the first decades of the sixteenth century, when Machiavelli, drawing on the ancient Latin and Greek authors, was able to propose a new republicanism, which was to become one of the leading political ideas of modern Europe. And now, we must once again face the ancient, Ciceronian, problem, seeking to reconcile the two different political principles of cosmopolitanism and civic citizenship at a global level.

KEYwORDS - city-state model; world-state model; cosmopolitanism; stoicism; Greek political thought; Roman political thought; empire; hegemony; dual citizenship; classical tradition; republicanism; globalization. 


\section{InTRODUCTION}

I begin with a quote from the introduction of an old book, which on the other hand is of primary interest for my topic - City-State and World State in Greek and Roman Political Theory until Augustus; it is a book published in 1951 by Mason Hammond, Professor of Latin Language and Literature in Harvard University from 1950 until his retirement in 1973. "This book", the author said, "is concerned primarily with the conflict between the dominant political concept of the city-state, as established by Aristotle and Plato..., and the pressing need to find some theoretical basis for the larger political organizations which arose in fact in the Hellenistic and Roman periods". According to professor Hammond, Aristotle's authority "prevented later political thinkers from developing a theoretical framework for the world state, whether of the Persians, of Alexander (the Great), or of the Romans. The city-state," he observes, "remained canonical for Cicero, Augustus, and even St. Augustine". The American scholar ended with a sort of warning: "the significant value of the ancient experience for modern studies lies... in its intellectual inability to escape from a dominant concept and to find a theoretical basis for the world state which had in practice become the necessary form of political organization... It is the author's persuasion that one of the principal lessons taught by the experience of the Greeks and Romans is that too great respect for tradition is fatal to any society" ${ }^{1}$. We shall return to this last point at the end; but first of all, let us focus on the two main questions, closely connected to each other, which are posed in the initial part of Mason Hammond's passage, that of the absolute dominance of the city-state model - which we shall call the polis-model - and that of the inability of the ancients to find a theoretical model for political experiences other than that of the polis. It is easy to observe that, if it is not in fact possible to call into question the dominance of the polis-model in Plato's and Aristotle's political theory ${ }^{2}$, and the relative inability of ancient political thought to give a theoretical basis to the Hellenistic monarchies ${ }^{3}$, one cannot accept the idea that a world-state model absolutely did not exist in the later political thought either of the Greeks, or, even less so, of the Romans. In truth, the respective Greek and Roman ways of looking at the political organization cannot be considered one and the same cultural phenomenon. Indeed, the Romans took from the Greeks intellectual tools through which they were able, beginning with the end of the third century B.C., to give a theoretical shape to their own institutions, but it must be admitted that the special features of their centuries-old political experience led them to forge substantially new ideas from the Greeks. And they were, as we shall see,

\footnotetext{
${ }^{1}$ Hammond 1951: 1ff.

${ }^{2}$ Cambiano 1999: 15-31.

3 They availed themselves, however, of a strong scenographic equipment: see Virgilio
} 1999: 23-30. 
particularly sensitive to the very issue of the relations between the polis- and the world-state models.

\section{GREECE: POLIS}

In any case, the central position of the polis-model in the political thought of the greatest philosophers of the fourth century cannot be denied. It was the result of two converging factors: on the one hand, the fact itself that the polis, in the variety of its forms, had been for generations the most widespread Greek political system in mainland Greece, as well as in the Greek islands and the colonial world; on the other hand, the great success that the alliance of the Greek poleis had brought in the long struggle of the previous century against the Persian basileia. As for the first point, we can calculate, excluding the colonial world, approximately 750 poleis, the great majority of which were very small states, their overall population amounting to two-three thousand people, and their territory to a few hundred square kilometres - excluding of course the very limited number of major poleis, like Athens, Sparta, or Syracuse in Sicily ${ }^{4}$. As for the second, the battles of Marathon, Salamis and Plataea in the first two decades of the Fifth Century - and many other military successes in the following period had demonstrated that, despite their numerical inferiority, the armies and fleets set up by coalitions of Greek cities were able to gain victory over the enormous Persian military power. Such a striking result could only be achieved - this was the most widely held idea - because the Greek poleis, with all their institutional differences, were communities of free citizens, each of whom, at least in principle, participated to various degrees in the management of common affairs; as a consequence, each of them was deeply concerned with the life of his community, and in their capacity as soldiers they were completely dedicated to preserving its safety and welfare. Even where kings existed, such as in Sparta, their power was severely limited by other magistrates or assemblies, which were an expression of the common citizens' political strength. By contrast, in the Persian system, as it was seen by the Greeks, power was concentrated in the hands of a single person, the great king, and all the other inhabitants of that immense empire were in a way his slaves: therefore, the troops of his army had no real interest in the result of the wars, and, as Aeschylus or Herodotus put it, even had to be forced to fight against the enemy. One could say that it was simply the memory of the Persian wars that caused the Greeks to largely disdain the monarchical way of government: although actually, in the same years in which Plato theorized the polis-model, other Greek intellectuals, like Xenophon and Isocrates, passed positive judgements on single monarchs, like Cyrus the Great in Persia itself, and Evagoras or Nicocles on the island of Cyprus, respectively ${ }^{5}$. Monarchy, after all,

\footnotetext{
${ }^{4}$ Asheri 1999: 33ff.

${ }^{5}$ Desideri 2015: 302ff.
} 
had been the governmental formula preferred by the Homeric Achaeans, and in the sixties of the fourth century, monarchy was the political regime of the state which would become the most important one in the Greek world: the Macedonian state.

\section{Alexander's $A R C H E$}

Thus, in the middle of that century monarchy can be said to have been fully legitimated as a form of government: actually, in that period, "the demonized image of the despot was fading, giving way to the positive and reassuring one of the good sovereign, depositary of political wisdom and ethic virtues" (to quote the Italian historian of ancient political thought, Silvia Gastaldi) ${ }^{6}$. In any event, the big news of the era was, immediately afterwards, the destruction of the Persian empire itself by Alexander, an event which forced the Greek world to face the problem of how to manage politically such a vast territory. Alexander's early death prevented him from building a stable world-state system - which would probably have been his aim - and the struggles among his generals resulted in the formation of a number of territorial states ruled by kings. From the point of view of what could be called the Greek political philosophy, the main consequence of Alexander's overall victory was, in any case, a de facto impairment of the polis-model, and the emergence of a cosmopolitan idea, which was apparently the centre of the Politeia written by Zeno, the founder of the Stoic philosophy ${ }^{7}$. Due to the loss of that work, there is much debate among the scholars as to how important that idea was in Zeno's mind; in particular it is difficult to understand if it ever had a truly political dimension or not. Plutarch, who wrote much later, at the end of the first century A.D., said that this Politeia "may be summed up in this one main principle: that all the inhabitants of the world of ours should not live differentiated by their respective rules of justice into separate cities and communities, but that we should consider all men to be one community and one polity, and that we should have a common life and an order common to us all, even as a herd that feeds together and shares the pasturage of a common field". Plutarch added that Zeno "gave shape to a dream or, as it were, shadowy picture of a well-ordered and philosophic commonwealth; but it was Alexander who gave effect to the idea" ${ }^{8}$. According to these passages, Zeno translated Alexander's supposed project of a world-state into theoretical terms: in other words, he created a model from which others would eventually draw; and it is likely, in my opinion, that Plutarch used this Politeia as a potential model for the Roman empire of his own times'.

\footnotetext{
${ }^{6}$ Gastaldi 2008: 134ff.

${ }^{7}$ Konstan 2009; Richter 2011: 55ff.

${ }^{8}$ Mor., 329ad.

${ }^{9}$ Desideri 2005.
} 


\section{Rome I: “vrbs Imperiosa” (Cic., Rep. 1. 3; 3. 36)}

Before examining the Roman empire, however, we must consider the Roman res publica, a political system which the Greek thinkers and historians as early as Heraclides Ponticus - living in the first half of the fourth century - had always considered a polis ${ }^{10}$. It is difficult, of course, to realize what the Romans themselves thought of their politeia in the early days of the republican period, but probably Livy was not so far from truth when he said that res publica - which came after the overthrow of a monarchy - was characterized by "annually elected magistrates, and the authority of laws supreme over all the citizens"11. The accent falls here on the rights of the citizens with respect to the power of the rulers, rather than, as in Greece, on their common political responsibility, but the analysis of Livy's historical accounts reveals that this aspect too was vital to the Roman political and military institutions. In any event, it was the Greek Polybius who, in the middle of the second century B.C, first gave a theoretical dimension to the political edifice built by the Romans, when investigating, in his capacity as political prisoner, the reasons why Rome in a very short amount of time had become the ruler of the entire Mediterranean world. As is well known, in his opinion the successes of the Romans were due to the superiority of their constitutional system (politeia), as compared even to the best of the Greek world. From this point of view, Polybius considered the Roman republic a polis provided with the best possible politeia, that is a 'mixed' one, whose main advantage was that it produced a very strong cohesion among the citizens, especially in difficult situations. But - Polybius added - the Roman mixed constitution was superior even to the most refined of Greek mixed constitutions: the famous Lycurgan constitution of the Spartans; in fact, it did not just guarantee stability and long duration to the Roman state, but ensured it a steady growth as well. Summing up a long digression on the final failure of the Spartan hegemonia, Polybius observed, at the end of the celebrated sixth book of his Histories, that "for the purpose of remaining in secure possession of their own territory and maintaining their freedom the legislation of Lycurgus is amply sufficient, and to those who maintain this to be the object of political constitutions we must admit that there is not and never was any system or constitution superior to that of Lycurgus. But if anyone is ambitious of greater things, and esteems it finer and more glorious than that to be the leader of many men and to rule and lord over many and have the eyes of all the world turned to him, it must be admitted that from this point of view the Laconian constitution is defective, while that of Rome is superior and better framed for the attainment of power, as is indeed evident from the actual course of events. For when the Lacedaemonians endeavoured to obtain supremacy in Greece, they very soon ran the risk of losing their own liberty; whereas

\footnotetext{
${ }^{10}$ Plu., Cam. 22. 3.

${ }^{11}$ Liv. 2. 1.
} 
the Romans, who had aimed merely at the subjection of Italy, in a short time brought the whole world under their sway..."12 .

It is therefore no surprise that Polybius, despite his appreciation of Rome as a polis, began his Histories with a comparison between the great 'empires' of the past - especially that of the Persians - and the Roman empire: a comparison that highlighted the superiority of the latter, above all in terms of territorial estension and ability to last. It is clear for Polybius that, no matter what the Romans themselves might think of their political construction, at that time Rome was no longer a city, but rather - in Polybian Greek - an arche, that is, in the Latin language - as we are going to see - an imperium ${ }^{13}$. The above quoted Polybian passage is in fact the oldest testimony of the historical idea of Rome as a polis which had developed an arche (which the Greek themselves had never been able to achieve), that is, as an 'imperial republic' - to use an expression which the Americans coined al the end of the nineteenth century to distinguish, even from a linguistic point of view, their empire from the empires of Europe, and in particular from the British Empire, which was of course a royal, that is a despotic, one $^{14}$. In any case, as we all know, a long series of civil wars produced the dissolution of the Roman republican structure, and the establishment of a new political system based on the monarchical (although disguised) power of Augustus ${ }^{15}$. But the end of the respublica gave way to that nostalgic idealization of the former regime which underlies the historical reconstruction of the early history of the city by Livius. "Unless I am misled by affection for my undertaking, there has never existed any commonwealth greater in power, with a purer morality, or more fertile in good examples; or any state in which avarice and luxury have been so late in making their inroads, or poverty and frugality so highly and continuously honoured, showing so clearly that the less wealth men possessed the less they coveted"16. Thanks to Livy's Ab urbe condita, in fact, the Roman republican period became, in the modern age, the most celebrated example of the polis-model in antiquity. But in Livy's own times, the idea that the Roman state then represented an empire - that is, a world-state model - had definitely taken the upper

12 Plb. 6. 50.

${ }^{13}$ Desideri 2013.

${ }^{14}$ The expression "imperial republic" was used - probably for the first time - in 1896 by the American journalist Marse Henry Watterson, who had served as a Democratic representative in Congress from 1876 to 1877 (for Kentucky). Writing about the United States, in the typical emphatic style of those years, he said: "We are a great imperial Republic, destined to exercise a controlling influence upon the actions of mankind and to affect the future of the world as the world was never affected, even by the Roman Empire" (quoted by Healy 1970: 46). At that time (and even later, until not so many years ago), the use of "empire" for the US would appear not only strange but offensive as well (Cox 2005: 39).

${ }^{15}$ See now Desideri 2014.

${ }^{16}$ Praef. 11. 
hand. In fact, the word imperium, which is originally the technical definition of the legal power of a magistrate, had already long acquired the sense of '(Roman) empire': and it is worth recalling that from the very beginning of the second century the 'national' poet Ennius had spoken of Rome in his Annals as an imperiosa urbs, that is "a city which governs an empire" 17 .

\section{ROME II: IMPERIVM ${ }^{18}$}

The evidence for this use of 'empire' (and derivatives) becomes more common, of course, in the final decades of the Republican period, but we shall simply cite, for its lofty ideological inspiration, the passage of De officiis in which Cicero describes what in his opinion had been, and should return to be, the proper role of the Roman Empire. "As long as the empire of the Roman People maintained itself by acts of service, not of oppression, wars were waged in the interest of our allies or to safeguard our supremacy; the end of our wars was marked by acts of clemency or by only a necessary degree of severity; the senate was a haven of refuge for kings, tribes, and nations; and the highest ambition of our magistrates and generals was to defend our provinces and allies with justice and honour. And so our government could be called more accurately a protectorate of the world than an empire (patrocinium orbis terrae verius quam imperium)"19. This passage may be considered the oldest testimony, in classical literature, of a gratifying assessment of the role of an empire - or more precisely, the Roman Empire, which is of course the only true empire to the Romans, as we have just seen. The state of things described by Cicero has more of what today we would call a 'hegemony', rather than an 'empire', because Rome and the Roman senate appear as an international court of justice, which in a sense ensures the world lawful order and peace; but it is evident that having a major military force available is the necessary precondition for exercising such a role. Therefore it could be said that Cicero's description of the Roman Empire of the "good old days" represents the best possible translation into political terms of the philosophical commonwealth possibly envisaged by the Stoic Zeno. But, of course, "the Roman achievement still remains miles away from ... a truly world-embracing political political commonwealth of nations", to put it in Guido Schepens' terms ${ }^{20}$. And in any case Cicero himself is keenly aware that this empire, though conceived in the noblest way, poses serious problems to the city's institutions, as well as to the sense of political allegiance of the Roman citizens; and in a famous passage from the beginning of the second book of his De legibus Cicero arrives at formulating a sort of theory of

\footnotetext{
${ }^{17}$ Fr. 579 V. $=590$ S. (see Desideri 2013: 76ff.).

${ }^{18}$ For a synthetic profile of the Roman Empire, especially as regards its ideological aspects, see Desideri 2010.

${ }^{19}$ Off. 2. 26ff. (see now Desideri 2012a: 82 f).

${ }^{20}$ Schepens 1998: 146.
} 
a dual citizenship, that of one's original birthplace and that of the great empire within which this homeland is encompassed. "We consider both the place where we were born our fatherland, and also the city into which we have been adopted (sc. Rome). But that fatherland must stand first in our affection in which the name of republic signifies the common citizenship of all of us" ${ }^{21}$.

This problem would be perceived with particular intensity in the Greek world, where as late as at the beginning of the second century A.D. - the period when the integration of the Greeks into the Roman Empire was about to reach its peak - the already mentioned Plutarch thought that the Greek urban aristocracy ought not to hold offices in the central administration of the Roman government, but rather limit themselves to an engagement in local politics ${ }^{22}$. Plutarch himself, on the other hand, built the best monument to that integration with his Parallel Lives; and in his De fortuna Romanorum he expressed what must be considered one of the most ardent appreciations of the Roman Empire ever seen. In fact, he says that Rome "attached to herself not only the nations and peoples within her own borders, but also royal dominions of foreign peoples beyond the seas, and thus the affairs of this vast empire gained stability and security, since the supreme government, which never knew reverse, was brought within an orderly and single cycle of peace"23. And in the generation following Plutarch, the Smyrnean sophist Aelius Aristides in his Roman Oration went so far as to imagine the Roman Empire as a sort of federation of polis under the supreme direction of the emperor ${ }^{24}$. In this way, the ancient political thought tried to overcome the old dichotomy between the two fundamentally opposed political models of polis and imperium. Aristides' oration, which was delivered during the emperor Antoninus Pius' reign, is essentially a celebration as well as a legitimization of the imperial model, seen as a political system that encompasses, at least in theory, the entire ecumene. From this point of view, that oration recollects previous Stoic, as well as Neo-Pythagorean, ideas, attributing to the Roman Empire the ability to achieve in practice what until then had remained mere philosophical suggestions. Aristides' basic idea is in fact that the order created by the Romans had in a way politically unified mankind: "the whole inhabited world hapasa he oikoumene) prays all together, emitting, like an aulos after a thorough cleaning, one note with more perfect precision than a chorus; so beautifully is it harmonized by the leader in command" (29). He further specifies that the Romans "rule the whole inhabited world exactly as it were one city state" (36); and concludes, with a deliberate paradox, that the Romans have established all over the world a true democracy (38): "a single universal democracy has been established

\footnotetext{
${ }^{21}$ Leg. 2. 5.

${ }^{22}$ Desideri 2003 (2012b): 15); Desideri 2011a (2012b): 128.

${ }^{23}$ Mor., 316ff.

${ }^{24}$ Aristid., Or. 26. 92ff.; see now Aristides' text in Elio Aristide 2007.
} 
under one, the best, ruler and teacher of order" $(60)^{25}$. The same idea, in more sober terms, would be expressed a few years later by the emperor who succeeded Antoninus, the Stoic Marcus Aurelius, who said that, in performing his duties as an emperor, he was animated by "the idea of a polity in which there is the same law for all, a polity administered with regard to equal rights and equal freedom of speech, and the idea of a kingly government which respects most of all the freedom of the governed" ${ }^{26}$. But it is easy to observe that in Marcus' reflection there is no space at all for any idea of municipal organization, and it is even more evident that in the decades to follow the emperor grew less and less responsible towards the subjects, until the imperial system became an entirely despotic mode of government under Diocletian.

\section{Modern ECHOES OF AN ANCIENT DEBATE}

The Roman Empire - that is, a sort of realization of a world-state model, to resume Mason Hammond's terminology, with which we began our reflections - was due to remain the final political experience of the ancient world; in a way, it was also reinforced by the Christian religion, which after a long struggle recognized the Empire's role as the necessary instrument for the governance of the human world, and gave it an even stronger religious consecration than paganism had ever done. As is well known, that event that Europeans have been accustomed to considering the end of the (Western) Roman Empire from the Renaissance on - Odoacre's bestowal of the imperial insignia upon the emperor Zeno in 476 A.D. - in the eyes of the contemporaries and throughout the Middle Ages was simply seen as the conclusion of the migration of the seat of the empire from Rome to Constantinople, the New Rome. Nearly five centuries later, that migration was balanced out by a re-foundation of the empire in Europe: on the famous Christmas night of 800 A.D. the Roman Empire came back, so to speak, to Rome, giving rise, at the hands of Charlemagne king of the Franks and of Pope Leo III, to the Holy Roman Empire. That empire was considered a sort of legitimate heir to the old empire, even though a Roman (Byzantine) empire survived in Constantinople at the same time. Dante Alighieri, the celebrated Italian poet who lived at the turn of the thirteenth and the fourteenth centuries, did not have the slightest doubt that the Holy Empire of his own times was the mere continuation of the old Roman empire, being endowed with the same powers and prerogatives whose description can be found in the Corpus iuris ${ }^{27}$. They represented what by then was known as the temporal sphere of power, which according to Dante came to the Emperor directly from God: in the same way in

\footnotetext{
${ }^{25}$ For a general reassessment of Aelius Aristides' political personality, see now the essays collected in Desideri - Fontanella (edd.) 2013.

${ }^{26}$ M.Ant. 1. 14.

${ }^{27}$ On Dante's ideas about empire, see now Fontanella 2016.
} 
which the spiritual sphere of power came to the Pope directly from God. Even though during the High Middle Ages, anyway, a differentiation was introduced between the two bodies of powers - the political and the religious - no space at all was left, from a theoretical point of view, for the polis-model which had been so important both in Greek and in Roman civilizations. Certainly, in the Late Middle Ages, beginning with Northern and Central Italy, a new social and political form developed, that of the comuni - municipalities - which, like the ancient poleis, usually had very small territorial dimensions, that of a town and its immediate outskirts; but although these new socio-political entities claimed some independence from the imperial power, none of them would ever claim a complete autonomy from it, which could have been the premise for asserting the right to build a political organization of a totally new type. The polis-model, which had completely disappeared, had to be refounded; and that refoundation was only possibile by looking back to the ancient authors, through whom that model could be recovered ${ }^{28}$.

And I shall close my speech by very briefly recalling at least the beginnings of such a process, that is, the role played in the renewed legitimization of the polis-model - which later gave rise to the line of political thought called "republicanism" - by Italian humanism, and in particular by the Florentine political thinker Niccolò Machiavelli ${ }^{29}$. Both in his Discorsi sopra la prima deca di Tito Livio, written in 1513, and in his more famous Principe, Machiavelli stressed first of all the natural origin of the state, which was to be considered not an instrument for preparing men for their final destination in the best possible way, but as the result of men's natural tendency toward life in society. Basing his thought on this principle, which had already been affirmed by the Aristotelian philosophers of the fifteenth century, in the first of the above mentioned works Machiavelli conducted a careful reading of Livy's Ab urbe condita - especially, but not exclusively, the First Decade - in order to determine what might be considered the real foundations of political life in a republican state. Machiavelli was a politician as well as a political thinker, and he was able to read Livy in the light of his political experience; but it is evident that Livy - as well as the many other Greek and Roman historians he consulted in the course of his work, first among them Polybius' above-mentioned sixth book - aided his undertaking considerably, especially as Livy's lesson was - so to speak - validated by the great accomplishments of the Roman republic ${ }^{30}$. Thanks to Machiavelli, and to his study of the ancient authors, which brought to light the importance not only of republican

${ }^{28}$ On the steady presence of the (Roman) imperial model in modern European history and political theory, see Desideri 1991; Roda 2011.

${ }^{29}$ For a general outline of the entire process see Cambiano 2000.

${ }^{30}$ Giarrizzo 1999: 68 ("Roma è da sempre il luogo classico della polarità Impero-Piccolo stato”); Millar 2002; Vlassopoulos 2010. 
Rome but of the great Greek poleis, such as Athens and Sparta, as well - the polis - model was reintroduced in the European political culture of the seventeenth, eighteenth, and early-nineteenth centuries ${ }^{31}$; and in the twentieth centuries it served as a healthy means of defence against the aggressiveness of the big states, which had badly disfigured the ancient cosmopolitan ideas revived in the age of Enlightenment, and in particular by Immanuel Kant ${ }^{32}$. Finally, coming back to Mason Hammond's last passage quoted earlier, even now, when the problem of so-called globalization is a highly topical issue, one should probably say that the real shortcoming of the ancients was that they were not able to better develop a model of integration between city- and world-states; in fact, what we really need today is not more imperium, but rather more polis.

\section{BibliogRAPHY}

Asheri, D. (1999), "Al di là di Atene e di Sparta: la 'polis normale’ e il 'Terzo Mondo' greco”, in E. Gabba and A. Schiavone (edd.), Polis e piccolo stato tra riflessione antica epensiero moderno. Atti delle Giornate di Studio 21-22 Febbraio 1997 Firenze. Como, 32-47

Bowden, B. (2009), The Empire of Civilization: the Evolution of an Imperial Idea. Chicago - London

Cambiano, G. (1999), "Polis e piccolo stato in Platone e Aristotele", in E. Gabba and A. Schiavone (edd.), Polis e piccolo stato tra riflessione antica e pensiero moderno. Atti delle Giornate di Studio 21-22 Febbraio 1997 Firenze. Como, 15-31

Cambiano, G. (2000), Polis. Un modello per la cultura europea. Roma-Bari

Cox, M.E. (2005 ), "La repubblica imperiale rivisitata: gli Stati Uniti nell'era Bush", Biblioteca della libertà 40: 35-54

Desideri, P. (1991), “La romanizzazione dell' Impero", in Storia di Roma II, 2. Torino, 577-626

Desideri, P. (2003), "Roma e la Grecia: una cultura per due popoli”, Studi Ellenistici 15: 229-243 [quoted from Desideri 2012b, 5-16]

${ }^{31}$ Gabba 1999: 10ff.; Giarrizzo 1999: 68ff. As regards the role of this model in the context of the Italian "risorgimento" see Desideri 2011b.

${ }^{32}$ For the tradition of Stoic cosmopolitan ideas in modern European political thought see Bowden 2009: $90 \mathrm{ff}$. 
Desideri, P. (2005), "Impero di Alessandro e impero di Roma secondo Plutarco", in A. Casanova (ed.), Plutarco e l'età ellenistica. Atti del Convegno internazionale di Studi Firenze, 23-24 settembre 2004. Firenze, 3-21

Desideri, P. (2010), "L'impero romano", in R. Romanelli (ed.), Impero, imperi. Una conversazione. Napoli-Roma, 35-63

Desideri, P. (2011a), "Greek Poleis and the Roman Empire: nature and features of political virtues in an autocratic system", in G. Roskam and L. Van der Stockt (edd.), Virtues for the People: Aspects of Plutarchan Ethics (Plutarchea Hypomnemata). Leuven, 83-98 [quoted from Desideri 2012b, 125-139]

Desideri, P. (2011b), "Gli Etruschi di Giuseppe Micali fra antiquaria e ideologia politica”, in G.M. Della Fina (ed.), La fortuna degli Etruschi nella costruzione dell'Italia unita. Atti del XVIII Convegno Internazionale di Studi sulla Storia e l'Archeologia dell'Etruria. Orvieto, 7-21

Desideri, P. (2012a), "Impero romano e diritto di natura in Cicerone", in M. Citroni (ed.), Letteratura e civitas. Transizioni dalla Repubblica all'Impero. In ricordo di Emanuele Narducci. Pisa, 73-87

Desideri, P. (2012b), Saggi su Plutarco e la sua fortuna, raccolti a cura di A. Casanova. Firenze

Desideri, P. (2013), "Terminologia imperiale in Polibio", in M. Mari and J. Thornton (edd.), Parole in movimento. Linguaggio politico e lessico storiografico nel mondo ellenistico. Atti del Convegno internazionale Roma, 21-23 febbraio 2011, Studi ellenistici 27: 71-79

Desideri, P. (2014), "Augusto e il classicismo", in S. Roda and G. De Blasio (edd.), Il "perfetto inganno". Augusto e la sua politica nel bimillenario della morte. Atti del Colloquium Augusteum, Torino 27 febbraio 2014. Torino, $18-30$

Desideri, P. (2015), “L'immagine dell'imperatore nei discorsi 'Sulla regalità di Dione di Prusa", in J.L. Ferrary and J. Scheid (edd.), Il princeps romano: autocrate o magistrato? Fattori giuridici e fattori sociali del potere imperiale da Augusto a Commodo. Pavia, 293-325

Desideri, P. and Fontanella, F. (edd.) (2013), Elio Aristide e la legittimazione greca dellimpero di Roma, Bologna

Elio Aristide (2007), A Roma, con trad. e comm. a cura di F. Fontanella. Pisa

Fontanella, F. (2016), L'impero e la sua storia di Roma in Dante, Bologna.

Gabba, E. (1999), "Riflessioni attorno all'idea di polis", in E. Gabba and A. Schiavone (edd.), Polis e piccolo stato tra riflessione antica e pensiero moderno. Atti delle Giornate di Studio 21-22 Febbraio 1997 Firenze. Como, 8-14 Gastaldi, S. (2008), Introduzione alla storia del pensiero politico antico. Roma-Bari 
Giarrizzo, G. (1999), "Il piccolo stato nella storia moderna", in E. Gabba and A. Schiavone (edd.), Polis e piccolo stato tra riflessione antica e pensiero moderno. Atti delle Giornate di Studio 21-22 Febbraio 1997 Firenze. Como, 67-75

Hammond, M. (1951), City-State and World State in Greek and Roman Political Theory until Augustus. Cambridge, Mass.

Healy, D. (1970), US Expansionism, the Imperialist Urge in the 1890s. Madison, Wisconsin

Konstan, D. (2009), "Cosmopolitan traditions", in R.K. Balot (ed.), A Companion to Greek and Roman Political Thought. Singapore, 473-484

Millar, F. (2002), The Roman Republic in Political Thought. Hanover and London

Richter, D.S. (2011), Cosmopolis. Imagining Community in Late Classical Athens and the Early Roman Empire. Oxford

Roda, S. (2011), Il modello della repubblica imperiale romana fra mondo antico e mondo moderno Milano

Schepens, G. (1998), "Between Utopianism and Hegemony. Some Reflections on the Limits of Political Ecumenism in the Graeco-Roman world", in L. Aigner Foresti et alii (edd.), L'ecumenismo politico nella coscienza dell'Occidente, Bergamo, 18-21 settembre 1995. Roma, 117-147

Virgilio, B. (1999), Lancia, diadema e porpora. Il re e la regalità ellenistica (Studi ellenistici 14, 2003, 2a ed.)

Vlassopoulos, K. (2010), Politics. Antiquity and its Legacy.London and New York 